\title{
PersianGulf: An Autonomous Combined Traffic Signal Controller and Route Guidance System
}

\author{
Mohammad Khanjary ${ }^{*}, 1$, Karim Faez ${ }^{* *}, 2$, Mohammad Reza Meybodi ${ }^{* * *, 3}$, Masoud Sabaei ${ }^{* * *, 4}$ \\ * Department of Engineering, Science and Research Branch, Islamic Azad University, Tehran, Iran \\ ${ }^{* *}$ Electrical Engineering Department, Amirkabir University of Technology, Tehran, Iran \\ ${ }^{* * *}$ Computer Engineering and Information Technology Department, Amirkabir University of Technology, Tehran, Iran \\ ${ }^{1}$ khanjary@srbiau.ac.ir ${ }^{2}$ kfaez@aut.ac.ir ${ }^{3}$ mmeybodi@aut.ac.ir ${ }^{4}$ sabaei@aut.ac.ir
}

\begin{abstract}
Traffic signal controllers and route guidance systems are two major subsystems of Intelligent Transportation Systems that influence each other directly. Due to correlation between these subsystems, some research has been done to combine them into an integrated system. In this paper, PersianGulf - an autonomous combined traffic signal controller and route guidance system - will be proposed which has two unique features as compared to similar research. First, it is totally distributed because calculation of optimal routes are done independently in traffic signal controllers of intersections and second, it is totally autonomous because there is no need to communicate/cooperate with either traffic supervisors such as traffic management centers or the vehicles/drivers. Also, Simulation results show that PersianGulf improve the average speed of vehicles significantly in the simulated scenarios.
\end{abstract}

\section{INTRODUCTION}

Route guidance systems (RGSs) are one of the major components of Intelligent Transportation Systems (ITS) and refer to all technologies which could be used by drivers to find the best routes according to static and dynamic parameters of traffic network before trips or enroute. Several RGSs have been already proposed based on different technologies such as agents (e.g. [1]), VANET (e.g. [2]), cellular automata (e.g. [3]), P2P (e.g. [4]), and wireless sensor networks (e.g. [5]).

Traffic Signal Controllers (TSCs) are another major subsystem of ITS. The main role of TSCs is adjusting traffic signal durations according to traffic flows. TSCs have been widely studied and several TSCs have been proposed so far base on different technologies such as wireless sensor networks (e.g. [6]), fuzzy-neural techniques (e.g. [7]), agents (e.g. [8]), fuzzy-genetic algorithm (e.g. [9]), dynamic programming (e.g. [10]) and Petri-nets (e.g. [11]). TSCs approaches can be categorized as follows [12]:

\section{A. a) Global Strategies}

1. Synchronized Strategies: In this approach, all adjacent traffic signals switch synchronously to green/red.

2. Green-wave Strategies: In this approach, adjacent traffic signals switch after a predefined offset.

3. Random Strategies: In this approach, adjacent traffic signals switch after a random offset.

\section{B. b) Adaptive Strategies}

1. Switching based on the queue length: In this approach, a traffic signal switches to green if length of vehicle queue behind the red light trespasses a certain threshold.

2. Switching based on waiting time: In this approach, the traffic signal switches from green to red if the green light is not used by any vehicle for a certain threshold.

3. Switching like a neural network: In this approach, the number of passed vehicles is calculated and determines the cycle times of a traffic signal by using neural network.

The RGSs and TSCs influence each other directly: 1) Most of RGSs only take into account the passing time of roads and ignore the waiting times for passing the intersections, whereas, the delay of passing intersections are also important. 2) When the number of RGSs users increases, traffic flow of traffic network will change. Therefore, RGSs affect TSCs too [13]. Indeed, these subsystems guide the traffic flow from temporal and spatial aspects, respectively. Therefore, the integration of these two subsystems could be very useful.

There are some researches to conceptually define the structure and elements of a Combined Traffic Signal Controller and Route Guidance (CTSCRG) system [1415], find the user equilibrium and mathematically model it [16]. A complete review on user equilibrium and proposed algorithms can be found in [16]. In [17-18], the authors proposed a theoretical architecture to integrate urban traffic control subsystem and route guidance subsystem based on agents. In this system, an agent will be set for traffic signal control and an agent will be set for

\footnotetext{
* The Persian Gulf is located in the southwest of the Asian Continent at 23 to 30 degrees northern latitude and 48 to 56 degrees longitude on the south side of the vast country of Iran, with a length of 1259 kilometer. The researchers, who have researched about the name of Persian Gulf, became unanimous considering the name of Persian Gulf. During all the centuries, and at least during the past 2500 years, i.e. as of the time of the powerful Pars Empire there has never been seen such a unanimity in the Middle East among writers and historians on one name during history. (Reference: Working Paper No. 61, UNITED NATIONS; GROUP OF EXPERTS ON GEOGRAPHICAL NAMES, Twenty-third Session, Vienna, 28 March - 4 April 2006, online: http://unstats.un.org/unsd/geoinfo/UNGEGN/docs/23-gegn/wp/gegn23wp61.pdf, accessed June 4th, 2011)
} 
dynamic route guidance. Since, in the future all subsystems of ITS will be integrated as one system, this system has been claimed as a good start to achieve this goal.

In $[3,19]$, the authors proposed a centralized CTSCRG based on hybrid genetic algorithm and cellular automata. Roads are discretized by cellular automata and traffic flow dynamics have been represented by cell transmission model and signal setting is optimized by a hybrid genetic algorithm. Due to centralized structure, this system has single point of failure disadvantage.

Recently, we proposed an autonomous dynamic route guidance system called UTOSPF based on wireless sensor networks $[5,20]$. In this system, street sensor nodes estimate speed of passing vehicles and send it to the intersection nodes. Then, intersection nodes calculate the estimated time to pass all their surrounding streets around them by using estimated speeds and exchange them with other intersection nodes. After exchanging, each intersection node will have the estimated time to travel all streets and simply calculates the optimal routes from it to other intersections. The main disadvantage of this system is need to deployment of many sensor nodes and access point all over the traffic network.

In this paper, we are going to eliminate this requirement by using information of traffic signal controllers in a distributed manner. To do this, firstly we adjust the traffic signal durations by a hierarchical fuzzy system based on priority of streets and length of stopped vehicle queue behind the intersections and then, we use the information of traffic signal controllers to find the optimal routes.

The rest of this paper is organized as follows. Section II explains the PersianGulf structure. Section III explains our simulation and presents its results and finally, section IV concludes our paper.

\section{PERSIANGULF}

\section{A. Traffic Signal Controller}

As [21], PersianGulf has three layers. At the first layer, priority of each street is calculated for current time. At the second layer, real speed of vehicles in streets is calculated. Then, the estimated real speed will be converted to cell movement and the cellular automata which represent the situation of streets will be updated. Finally, at the third layer, by using the priority of streets and current situation in cellular automata, the traffic light will be adjusted and also, by exchanging the real speed between all traffic signal controllers, each controller calculates the best routes from itself (this intersection) to other controllers (intersections). The structure of PersianGulf has been shown in Fig. 1.

\section{1) First Layer}

Pausing coefficient of vehicles in streets could be used as a significant factor to determine priority of streets. Streets with more stopped or paused vehicles have more potential priority. Since, number of business centers is an important factor to extract the potential paused vehicles (clients) of one street, as [21], the pausing coefficient have been classified to three main categories by using fuzzy sets: a) sport clubs, leisure-time activities and health centers (Fig. 2) b) official centers (Fig. 3) and c) shopping/commercial centers (Fig. 4).

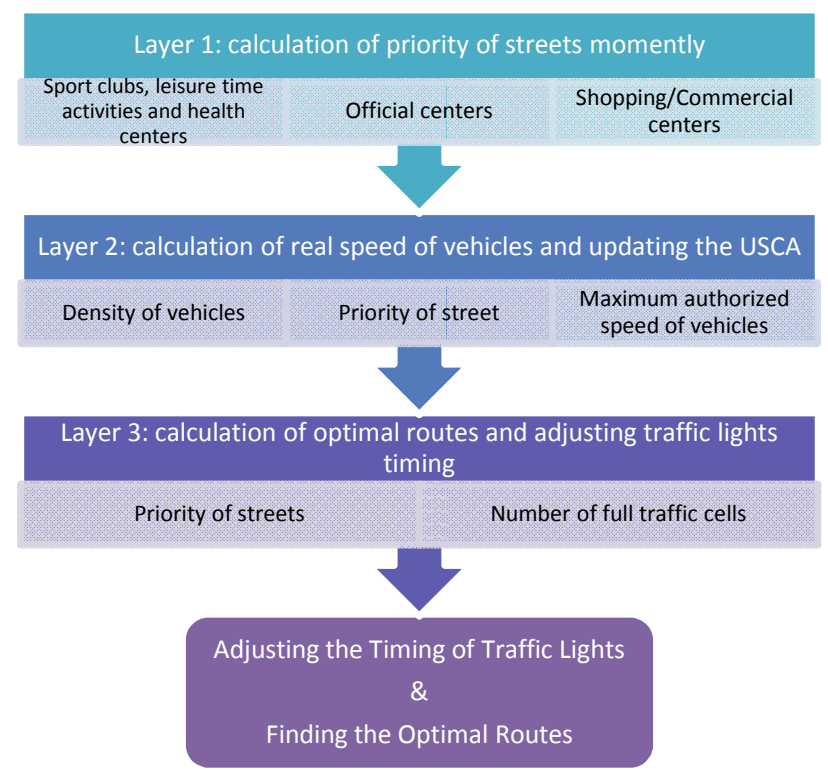

Fig. 1. PersianGulf Structure.

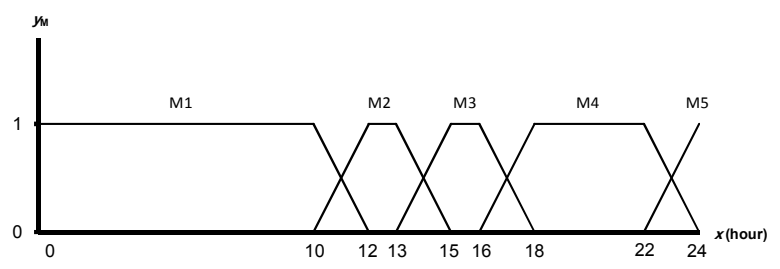

Fig. 2. Fuzzy sets for density of clients of sport clubs, leisure-time activities and health centers. M1, M2, M3, M4, M5 fuzzy sets are related to low, high, medium, high and medium densities, respectively.

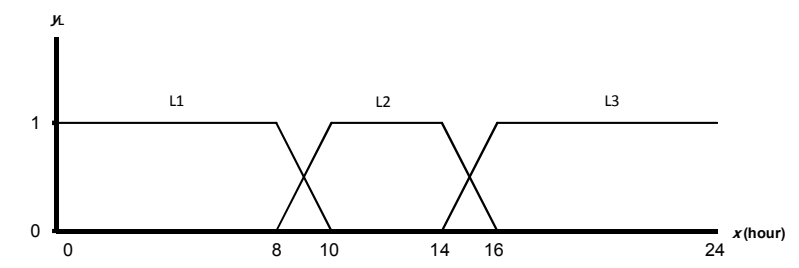

Fig. 3. Fuzzy sets for density of clients of official centers. L1, L2, L3 fuzzy sets are related to low, high and low densities, respectively.

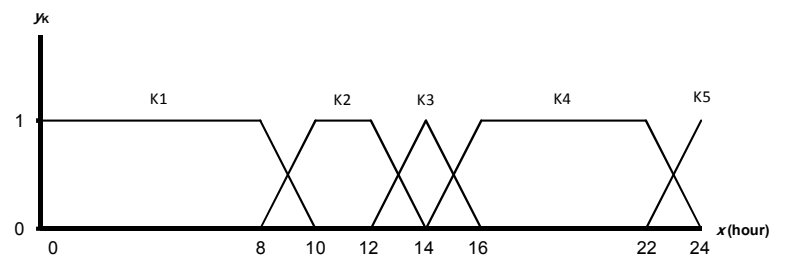

Fig. 4. Fuzzy Sets for density of clients of shopping/commercial centers. $\mathrm{K} 1, \mathrm{~K} 2, \mathrm{~K} 3$, K4, K5 fuzzy sets are related to low, high, medium, high and low densities, respectively.

According to the fuzzy sets of Fig. 2, 3 and 4, 26 fuzzy rules could be defined among all rules ( 75 rules) as table 
I. In table I, $y_{\mathrm{M}, \mathrm{j}}, y_{\mathrm{L}, \mathrm{j}}$ and $y_{\mathrm{K}, \mathrm{j}}$ represent membership functions of $\mathrm{Mj}, \mathrm{Lj}$ and $\mathrm{Kj}$ fuzzy sets respectively, and $A_{M}, A_{L}, A_{K}$ represent the constant number of health and commercial centers, official centers and shopping centers in each street, respectively.

TABLE I

Used FuZZy Rules AcCording to Defined FuZZy SETS

\begin{tabular}{|c|c|}
\hline No & Rule \\
\hline 1 & $\begin{array}{l}\text { IF }\left(x \text { is } \mathrm{M}_{1}\right) \text { AND }\left(x \text { is } \mathrm{L}_{1}\right) \text { AND }\left(x \text { is } \mathrm{K}_{1}\right) \text { THEN } \\
P_{1}=\left(\left[\mathrm{A}_{\mathrm{M}} *\left(1-y_{\mathrm{M}, 1}\right)\right]^{*}\left[\mathrm{~A}_{\mathrm{L}} *\left(1-y_{\mathrm{L}, 1}\right)\right]^{*}\left[\mathrm{~A}_{\mathrm{K}} *\left(1-y_{\mathrm{K}, 1}\right)\right]\right) /\left(\mathrm{A}_{\mathrm{M}} * \mathrm{~A}_{\mathrm{L}} * \mathrm{~A}_{\mathrm{K}}\right)\end{array}$ \\
\hline 2 & $\begin{array}{l}\text { IF }\left(x \text { is } \mathrm{M}_{1}\right) \text { AND }\left(x \text { is } \mathrm{L}_{1}\right) \text { AND }\left(x \text { is } \mathrm{K}_{2}\right) \text { THEN } \\
P_{2}=\left(\left[\mathrm{A}_{\mathrm{M}} *\left(1-y_{\mathrm{M}, 1}\right)\right]^{*}\left[\mathrm{~A}_{\mathrm{L}} *\left(1-y_{\mathrm{L}, 1}\right)\right]^{*}\left[\mathrm{~A}_{\mathrm{K}} * y_{\mathrm{K}, 2}\right]\right) /\left(\mathrm{A}_{\mathrm{M}} * \mathrm{~A}_{\mathrm{L}} * \mathrm{~A}_{\mathrm{K}}\right)\end{array}$ \\
\hline 3 & $\begin{array}{l}\text { IF }\left(x \text { is } \mathrm{M}_{1}\right) \operatorname{AND}\left(x \text { is } \mathrm{L}_{2}\right) \text { AND }\left(x \text { is } \mathrm{K}_{1}\right) \text { THEN } \\
P_{3}=\left(\left[\mathrm{A}_{\mathrm{M}} *\left(1-y_{\mathrm{M}, 1}\right)\right] *\left[\mathrm{~A}_{\mathrm{L}} * y_{\mathrm{L}, 2}\right] *\left[\mathrm{~A}_{\mathrm{K}} *\left(1-y_{\mathrm{K}, 1}\right)\right]\right) /\left(\mathrm{A}_{\mathrm{M}} * \mathrm{~A}_{\mathrm{L}} * \mathrm{~A}_{\mathrm{K}}\right)\end{array}$ \\
\hline 4 & $\begin{array}{l}\text { IF }\left(x \text { is } \mathrm{M}_{1}\right) \text { AND }\left(x \text { is } \mathrm{L}_{2}\right) \text { AND }\left(x \text { is } \mathrm{K}_{2}\right) \text { THEN } \\
P_{4}=\left(\left[\mathrm{A}_{\mathrm{M}} *\left(1-y_{\mathrm{M}, 1}\right)\right] *\left[\mathrm{~A}_{\mathrm{L}} * y_{\mathrm{L}, 2}\right] *\left[\mathrm{~A}_{\mathrm{K}} * y_{\mathrm{K}, 2}\right]\right) /\left(\mathrm{A}_{\mathrm{M}} * \mathrm{~A}_{\mathrm{L}} * \mathrm{~A}_{\mathrm{K}}\right)\end{array}$ \\
\hline 5 & $\begin{array}{l}\text { IF }\left(x \text { is } \mathrm{M}_{1}\right) \operatorname{AND}\left(x \text { is } \mathrm{L}_{2}\right) \text { AND }\left(x \text { is } \mathrm{K}_{3}\right) \text { THEN } \\
\left.P_{5}=\left(\left[\mathrm{A}_{\mathrm{M}} *\left(1-y_{\mathrm{M}, 1}\right)\right]^{*}\left[\mathrm{~A}_{\mathrm{L}} * y_{\mathrm{L}, 2}\right] *\left[\mathrm{~A}_{\mathrm{K}} *\left(y_{\mathrm{K}, 3} / 2\right)\right]\right]\right) /\left(\mathrm{A}_{\mathrm{M}} * \mathrm{~A}_{\mathrm{L}} * \mathrm{~A}_{\mathrm{K}}\right)\end{array}$ \\
\hline 6 & $\begin{array}{l}\text { IF }\left(x \text { is } \mathrm{M}_{1}\right) \operatorname{AND}\left(x \text { is } \mathrm{L}_{2}\right) \text { AND }\left(x \text { is } \mathrm{K}_{4}\right) \text { THEN } \\
P_{6}=\left(\left[\mathrm{A}_{\mathrm{M}} *\left(1-y_{\mathrm{M}, 1}\right)\right]^{*}\left[\mathrm{~A}_{\mathrm{L}} * y_{\mathrm{L}, 2}\right] *\left[\mathrm{~A}_{\mathrm{K}} * y_{\mathrm{K}, 4}\right]\right) /\left(\mathrm{A}_{\mathrm{M}} * \mathrm{~A}_{\mathrm{L}} * \mathrm{~A}_{\mathrm{K}}\right)\end{array}$ \\
\hline 7 & $\begin{array}{l}\text { IF }\left(x \text { is } \mathrm{M}_{2}\right) \text { AND }\left(x \text { is } \mathrm{L}_{2}\right) \text { AND }\left(x \text { is } \mathrm{K}_{1}\right) \text { THEN } \\
P_{7}=\left(\left[\mathrm{A}_{\mathrm{M}} * y_{\mathrm{M}, 2}\right] *\left[\mathrm{~A}_{\mathrm{L}} * y_{\mathrm{L}, 2}\right] *\left[\mathrm{~A}_{\mathrm{K}} *\left(1-y_{\mathrm{K}, 1}\right)\right]\right) /\left(\mathrm{A}_{\mathrm{M}} * \mathrm{~A}_{\mathrm{L}} * \mathrm{~A}_{\mathrm{K}}\right)\end{array}$ \\
\hline 8 & $\begin{array}{l}\text { IF }\left(x \text { is } \mathrm{M}_{2}\right) \operatorname{AND}\left(x \text { is } \mathrm{L}_{2}\right) \operatorname{AND}\left(x \text { is } \mathrm{K}_{2}\right) \text { THEN } \\
P_{8}=\left(\left[\mathrm{A}_{\mathrm{M}} * y_{\mathrm{M}, 2}\right] *\left[\mathrm{AL}^{*} y_{\mathrm{L}, 2}\right]\left[\mathrm{A}_{\mathrm{K}} * y_{\mathrm{K}, 2}\right]\right) /\left(\mathrm{A}_{\mathrm{M}} * \mathrm{~A}_{\mathrm{L}} * \mathrm{~A}_{\mathrm{K}}\right)\end{array}$ \\
\hline 9 & $\begin{array}{l}\text { IF }\left(x \text { is } \mathrm{M}_{2}\right) \text { AND }\left(x \text { is } \mathrm{L}_{2}\right) \text { AND }\left(x \text { is } \mathrm{K}_{3}\right) \text { THEN } \\
P_{9}=\left(\left[\mathrm{A}_{\mathrm{M}} * y_{\mathrm{M}, 2}\right]\left[\mathrm{A}_{\mathrm{L}}{ }^{*} y_{\mathrm{L}, 2}\right] *\left[\mathrm{~A}_{\mathrm{K}} *\left(y_{\mathrm{K}, 3} / 2\right)\right]\right) /\left(\mathrm{A}_{\mathrm{M}} * \mathrm{~A}_{\mathrm{L}} * \mathrm{~A}_{\mathrm{K}}\right)\end{array}$ \\
\hline 10 & $\begin{array}{l}\text { IF }\left(x \text { is } \mathrm{M}_{2}\right) \operatorname{AND}\left(x \text { is } \mathrm{L}_{2}\right) \operatorname{AND}\left(x \text { is } \mathrm{K}_{4}\right) \text { THEN } \\
P_{10}=\left(\left[\mathrm{A}_{\mathrm{M}} * y_{\mathrm{M}, 2}\right]^{*}\left[\mathrm{~A}_{\mathrm{L}} * y_{\mathrm{L}, 2}\right]^{*}\left[\mathrm{~A}_{\mathrm{K}} * y_{\mathrm{K}, 4}\right]\right) /\left(\mathrm{A}_{\mathrm{M}} * \mathrm{~A}_{\mathrm{L}} * \mathrm{~A}_{\mathrm{K}}\right)\end{array}$ \\
\hline 11 & $\begin{array}{l}\text { IF }\left(x \text { is } \mathrm{M}_{3}\right) \text { AND }\left(x \text { is } \mathrm{L}_{2}\right) \text { AND }\left(x \text { is } \mathrm{K}_{1}\right) \text { THEN } \\
P_{11}=\left(\left[\mathrm{A}_{M} *\left(y_{\mathrm{M}, 3} / 2\right)\right]^{*}\left[\mathrm{~A}_{\mathrm{L}} * y_{\mathrm{L}, 2}\right] *\left[\mathrm{~A}_{\mathrm{K}} *\left(1-y_{\mathrm{K}, 1}\right)\right]\right) /\left(\mathrm{A}_{\mathrm{M}} * \mathrm{~A}_{\mathrm{L}} * \mathrm{~A}_{\mathrm{K}}\right)\end{array}$ \\
\hline 12 & $\begin{array}{l}\text { IF }\left(x \text { is } \mathrm{M}_{3}\right) \text { AND }\left(x \text { is } \mathrm{L}_{2}\right) \text { AND }\left(x \text { is } \mathrm{K}_{2}\right) \text { THEN } \\
P_{12}=\left(\left[\mathrm{A}_{\mathrm{M}} *\left(y_{\mathrm{M}, 3} / 2\right)\right]^{*}\left[\mathrm{~A}_{\mathrm{L}} * y_{\mathrm{L}, 2}\right]^{*}\left[\mathrm{~A}_{\mathrm{K}} * y_{\mathrm{K}, 2]}\right] /\left(\mathrm{A}_{\mathrm{M}} * \mathrm{~A}_{\mathrm{L}} * \mathrm{~A}_{\mathrm{K}}\right)\right.\end{array}$ \\
\hline 13 & $\begin{array}{l}\text { IF }\left(x \text { is } \mathrm{M}_{3}\right) \operatorname{AND}\left(x \text { is } \mathrm{L}_{2}\right) \operatorname{AND}\left(x \text { is } \mathrm{K}_{3}\right) \text { THEN } \\
P_{13}=\left(\left[\mathrm{A}_{\mathrm{M}} *\left(y_{\mathrm{M}, 3} / 2\right)\right]^{*}\left[\mathrm{~A}_{\mathrm{L}} * y_{\mathrm{L}, 2}\right]^{*}\left[\mathrm{~A}_{\mathrm{K}} *\left(y_{\mathrm{K}, 3} / 2\right)\right]\right) /\left(\mathrm{A}_{\mathrm{M}} * \mathrm{~A}_{\mathrm{L}} * \mathrm{~A}_{\mathrm{K}}\right)\end{array}$ \\
\hline 14 & $\begin{array}{l}\text { IF }\left(x \text { is } \mathrm{M}_{3}\right) \text { AND }\left(x \text { is } \mathrm{L}_{2}\right) \text { AND }\left(x \text { is } \mathrm{K}_{4}\right) \text { THEN } \\
P_{14}=\left(\left[\mathrm{A}_{M} *\left(y_{\mathrm{M}, 3} / 2\right)\right]^{*}\left[\mathrm{~A}_{\mathrm{L}} * y_{\mathrm{L}, 2}\right] *\left[\mathrm{~A}_{\mathrm{K}} * y_{\mathrm{K}, 4}\right]\right) /\left(\mathrm{A}_{\mathrm{M}} * \mathrm{~A}_{\mathrm{L}} * \mathrm{~A}_{\mathrm{K}}\right)\end{array}$ \\
\hline 15 & $\begin{array}{l}\text { IF }\left(x \text { is } \mathrm{M}_{2}\right) \text { AND }\left(x \text { is } \mathrm{L}_{3}\right) \text { AND }\left(x \text { is } \mathrm{K}_{3}\right) \text { THEN } \\
P_{15}=\left(\left[\mathrm{A}_{\mathrm{M}} * y_{\mathrm{M}, 2}\right] *\left[\mathrm{~A}_{\mathrm{L}} *\left(1-y_{\mathrm{L}, 3}\right)\right] *\left[\mathrm{~A}_{\mathrm{K}} *\left(y_{\mathrm{K}, 3} / 2\right)\right]\right) /\left(\mathrm{A}_{\mathrm{M}} * \mathrm{~A}_{\mathrm{L}} * \mathrm{~A}_{\mathrm{K}}\right)\end{array}$ \\
\hline 16 & $\begin{array}{l}\text { IF }\left(x \text { is } \mathrm{M}_{2}\right) \text { AND }\left(x \text { is } \mathrm{L}_{3}\right) \text { AND }\left(x \text { is } \mathrm{K}_{4}\right) \text { THEN } \\
P_{16}=\left(\left[\mathrm{A}_{\mathrm{M}} * y_{\mathrm{M}, 2}\right] *\left[\mathrm{~A}_{\mathrm{L}} *\left(1-y_{\mathrm{L}, 3}\right)\right]^{*}\left[\mathrm{~A}_{\mathrm{K}} * y_{\mathrm{K}, 4}\right]\right) /\left(\mathrm{A}_{\mathrm{M}} * \mathrm{~A}_{\mathrm{L}} * \mathrm{~A}_{\mathrm{K}}\right)\end{array}$ \\
\hline 17 & $\begin{array}{l}\text { IF }\left(x \text { is } \mathrm{M}_{2}\right) \operatorname{AND}\left(x \text { is } \mathrm{L}_{3}\right) \text { AND }\left(x \text { is } \mathrm{K}_{5}\right) \text { THEN } \\
P_{17}=\left(\left[\mathrm{A}_{\mathrm{M}}{ }^{*} y_{\mathrm{M}, 2}\right]\left[\mathrm{A}_{\mathrm{L}} *\left(1-y_{\mathrm{L}, 3}\right)\right]^{*}\left[\mathrm{~A}_{\mathrm{K}} *\left(1-y_{\mathrm{K}, 5}\right)\right]\right) /\left(\mathrm{A}_{\mathrm{M}} * \mathrm{~A}_{\mathrm{L}} * \mathrm{~A}_{\mathrm{K}}\right)\end{array}$ \\
\hline 18 & $\begin{array}{l}\text { IF }\left(x \text { is } \mathrm{M}_{3}\right) \text { AND }\left(x \text { is } \mathrm{L}_{3}\right) \text { AND }\left(x \text { is } \mathrm{K}_{3}\right) \text { THEN } \\
P_{18}=\left(\left[\mathrm{A}_{\mathrm{M}} *\left(y_{\mathrm{M}, 3} / 2\right)\right] *\left[\mathrm{~A}_{\mathrm{L}} *\left(1-y_{\mathrm{L}, 3}\right)\right]^{*}\left[\mathrm{~A}_{\mathrm{K}} *\left(y_{\mathrm{K}, 3} / 2\right)\right]\right) /\left(\mathrm{A}_{\mathrm{M}} * \mathrm{~A}_{\mathrm{L}} * \mathrm{~A}_{\mathrm{K}}\right)\end{array}$ \\
\hline 19 & $\begin{array}{l}\text { IF }\left(x \text { is } \mathrm{M}_{3}\right) \text { AND }\left(x \text { is } \mathrm{L}_{3}\right) \text { AND }\left(x \text { is } \mathrm{K}_{4}\right) \text { THEN } \\
P_{19}=\left(\left[\mathrm{A}_{\mathrm{M}} *\left(y_{\mathrm{M}, 3} / 2\right)\right]^{*}\left[\mathrm{~A}_{\mathrm{L}} *\left(1-y_{\mathrm{L}, 3}\right)\right]^{*}\left[\mathrm{~A}_{\mathrm{K}} * y_{\mathrm{K}, 4}\right]\right) /\left(\mathrm{A}_{\mathrm{M}} * \mathrm{~A}_{\mathrm{L}} * \mathrm{~A}_{\mathrm{K}}\right)\end{array}$ \\
\hline 20 & $\begin{array}{l}\text { IF }\left(x \text { is } \mathrm{M}_{3}\right) \text { AND }\left(x \text { is } \mathrm{L}_{3}\right) \text { AND }\left(x \text { is } \mathrm{K}_{5}\right) \text { THEN } \\
P_{20}=\left(\left[\mathrm{A}_{\mathrm{M}} *\left(y_{\mathrm{M}, 3} / 2\right)\right] *\left[\mathrm{~A}_{\mathrm{L}} *\left(1-y_{\mathrm{L}, 3}\right)\right] *\left[\mathrm{~A}_{\mathrm{K}} *\left(1-y_{\mathrm{K}, 5}\right)\right]\right) /\left(\mathrm{A}_{\mathrm{M}} * \mathrm{~A}_{\mathrm{L}} * \mathrm{~A}_{\mathrm{K}}\right)\end{array}$ \\
\hline 21 & $\begin{array}{l}\text { IF }\left(x \text { is } \mathrm{M}_{4}\right) \text { AND }\left(x \text { is } \mathrm{L}_{3}\right) \text { AND }\left(x \text { is } \mathrm{K}_{3}\right) \text { THEN } \\
P_{21}=\left(\left[\mathrm{A}_{\mathrm{M}} y_{\mathrm{M}, 4}\right]^{*}\left[\mathrm{~A}_{\mathrm{L}} *\left(1-y_{\mathrm{L}, 3}\right)\right]^{*}\left[\mathrm{~A}_{\mathrm{K}} *\left(y_{\mathrm{K}, 3} / 2\right)\right) /\left(\mathrm{A}_{\mathrm{M}} * \mathrm{~A}_{\mathrm{L}} * \mathrm{~A}_{\mathrm{K}}\right)\right.\end{array}$ \\
\hline 22 & $\begin{array}{l}\text { IF }\left(x \text { is } \mathrm{M}_{4}\right) \text { AND }\left(x \text { is } \mathrm{L}_{3}\right) \text { AND }\left(x \text { is } \mathrm{K}_{4}\right) \text { THEN } \\
P_{22}=\left(\left[\mathrm{A}_{\mathrm{M}} y_{\mathrm{M}, 4}\right]^{*}\left[\mathrm{~A}_{\mathrm{L}}^{*}\left(1-y_{\mathrm{L}, 3}\right)\right]^{*}\left[\mathrm{~A}_{\mathrm{K}} y_{\mathrm{K}, 4}\right]\right) /\left(\mathrm{A}_{\mathrm{M}} * \mathrm{~A}_{\mathrm{L}} * \mathrm{~A}_{\mathrm{K}}\right)\end{array}$ \\
\hline 23 & $\begin{array}{l}\text { IF }\left(x \text { is } \mathrm{M}_{4}\right) \text { AND }\left(x \text { is } \mathrm{L}_{3}\right) \text { AND }\left(x \text { is } \mathrm{K}_{5}\right) \text { THEN } \\
P_{23}=\left(\left[\mathrm{A}_{\mathrm{M}} * y_{\mathrm{M}, 4}\right] *\left[\mathrm{~A}_{\mathrm{L}} *\left(1-y_{\mathrm{L}, 3}\right)\right]^{*}\left[\mathrm{~A}_{\mathrm{K}} *\left(1-y_{\mathrm{K}, 5}\right)\right]\right) /\left(\mathrm{A}_{\mathrm{M}} * \mathrm{~A}_{\mathrm{L}} * \mathrm{~A}_{\mathrm{K}}\right) \\
\end{array}$ \\
\hline 24 & $\begin{array}{l}\text { IF }\left(x \text { is } \mathrm{M}_{5}\right) \operatorname{AND}\left(x \text { is } \mathrm{L}_{3}\right) \text { AND }\left(x \text { is } \mathrm{K}_{3}\right) \text { THEN } \\
P_{24}=\left(\left[\mathrm{A}_{M} *\left(y_{\mathrm{M}, 5} / 2\right)\right]^{*}\left[\mathrm{~A}_{\mathrm{L}} *\left(1-y_{\mathrm{L}, 3}\right)\right]^{*}\left[\mathrm{~A}_{\mathrm{K}} *\left(y_{\mathrm{K}, 3} / 2\right)\right]\right) /\left(\mathrm{A}_{\mathrm{M}} * \mathrm{~A}_{\mathrm{L}} * \mathrm{~A}_{\mathrm{K}}\right)\end{array}$ \\
\hline 25 & $\begin{array}{l}\text { IF }\left(x \text { is } \mathrm{M}_{5}\right) \text { AND }\left(x \text { is } \mathrm{L}_{3}\right) \text { AND }\left(x \text { is } \mathrm{K}_{4}\right) \text { THEN } \\
P_{25}=\left(\left[\mathrm{A}_{\mathrm{M}} *\left(y_{\mathrm{M}, 5} / 2\right)\right] *\left[\mathrm{~A}_{\mathrm{L}} *\left(1-y_{\mathrm{L}, 3}\right)\right] *\left[\mathrm{~A}_{\mathrm{K}} * y_{\mathrm{K}, 4}\right]\right) /\left(\mathrm{A}_{\mathrm{M}} * \mathrm{~A}_{\mathrm{L}} * \mathrm{~A}_{\mathrm{K}}\right)\end{array}$ \\
\hline 26 & $\begin{array}{l}\text { IF }\left(x \text { is } \mathrm{M}_{5}\right) \operatorname{AND}\left(x \text { is } \mathrm{L}_{3}\right) \text { AND }\left(x \text { is } \mathrm{K}_{5}\right) \text { THEN } \\
P_{26}=\left(\left[\mathrm{A}_{\mathrm{M}} *\left(y_{\mathrm{M}, 5} / 2\right)\right]^{*}\left[\mathrm{~A}_{\mathrm{L}} *\left(1-y_{\mathrm{L}, 3}\right)\right]^{*}\left[\mathrm{~A}_{\mathrm{K}} *\left(1-y_{\mathrm{K}, 5}\right)\right]\right) /\left(\mathrm{A}_{\mathrm{M}} * \mathrm{~A}_{\mathrm{L}} * \mathrm{~A}_{\mathrm{K}}\right)\end{array}$ \\
\hline
\end{tabular}

After computing the fuzzy rules, the result of rules will be defuzzified by using equation 1 . In this equation, $P_{\mathrm{k}}$ is output of $i$ th rule according to table $\mathrm{I}, \mathrm{n}$ is the number of rules with nonzero output and $\mathrm{P}_{\mathrm{i}, \mathrm{j}}$ is priority of the street between intersection $i$ and $j$ and output of first layer of system.

$$
\mathrm{P}_{\mathrm{i}, \mathrm{j}}=\frac{\sum_{k=1}^{26} \mathrm{P}_{\mathrm{k}}}{\mathrm{n}}
$$

\section{2) Second Layer}

In this layer, Unidirectional Selective Cellular Automata (USCA) [21] will be used to simulate the situation of streets and estimate the real average speed of vehicles in each street, momently. The USCA is a special type of cellular automata which is suitable to simulate traffic networks. There are two main differences between classic Cellular Automata (CA) and USCA: a) In classic CAs, next state of each cell is defined according to state of its left and right neighbors but in USCA, the next state is determined just based on neighbors of one side (according to direction of motion in streets). Due to this feature, the proposed CA is called "Unidirectional". b) In classic CAs, the next state of each cell only will be determined based on the adjacent neighbors. But in USCA, next state could be determined by some selected neighbor cells (even with considerable distance). Due to this feature, the proposed CA is called "Selective".

By using the priority of streets, density of vehicles and maximum authorized speed of each street, estimated average speed of vehicles in each street will be estimated by equation 2 and the USCA will be updated.

$$
\bar{v}_{i, j}=\left(1-\gamma_{i, j}\right)\left(1-P_{i, j}\right) M A S_{i, j}
$$

In equation $2, P$ is priority of the street (output of first layer), $\mathrm{MAS}_{\mathrm{i}, \mathrm{j}}$ is maximum authorized speed of street between intersection $i$ and $j$, and $\gamma_{i, j}$ is density of the street which will be obtained from equation 3 . In this equation, $\mathrm{N}_{\mathrm{i}, \mathrm{j}, \mathrm{k}}$ is number of available vehicles in cell $\mathrm{k}$ of the street and $n_{i, j}$ is number of cells in the street.

$$
\gamma_{\mathrm{i}, \mathrm{j}}=\frac{\sum_{k=1}^{\mathrm{n}_{\mathrm{i}, \mathrm{j}}} \mathrm{N}_{\mathrm{i}, \mathrm{j}, \mathrm{k}}}{\mathrm{M}_{\mathrm{i}, \mathrm{j}}}
$$

In equation $3, \mathrm{M}_{\mathrm{i}, \mathrm{j}}$ is maximum possible number of vehicles in the street which will be found by $M_{i, j}=\left(W_{i, j}\right.$ * $\mathrm{L}_{i, j}$ )/A where $\mathrm{W}_{\mathrm{i}, \mathrm{j}}$ and $\mathrm{L}_{\mathrm{i}, \mathrm{j}}$ are width and length of the street, respectively and $A$ is average required space for each vehicle which is assumed to be $15 \mathrm{~m}^{2}$. Based on estimated average speed of vehicles in each street $(\bar{v})$, transition rules of USCA are determined.

\section{a) Cellular Automata Rules}

For simplicity, estimated average speed of vehicles is discretized to $5 \mathrm{Km} / \mathrm{h}$ intervals. Also, the length of each cell has been assumed to be $10 \mathrm{~m}$. Therefore, based on defined speed intervals and length of cells, it takes 7.2 seconds for a vehicle to pass a cell. Fig. 5 shows the transition function of USCA based on discretized speed of vehicles. Cell transition (cell movement) of vehicles 
means transition of vehicles from one cell to another one. By using this transition function, the density of USCA will be updated. for instance, if the estimated average speed of vehicles in one street is $30 \mathrm{Km} / \mathrm{h}$, according to chart of Fig. 5, vehicles of each cell in this street moves 6 cells forward: $C(j+6)=C(j+6)+C(j)$ where $C(j+6)$ is 6 th neighbor cell of $\mathrm{C}(\mathrm{j})$ in the direction of street.

Maximum possible number of vehicles in each cell is computed as follows:

$$
\mathrm{M}_{\mathrm{C}}=\left(\mathrm{W}_{\mathrm{i}, \mathrm{j}} * \mathrm{H}_{\mathrm{C}}\right) / \mathrm{A}
$$

In Equation 4, $A$ is $15 \mathrm{~m}^{2}, \mathrm{H}_{\mathrm{C}}$ is height of cells which assumed to be $10 \mathrm{~m}$ and $\mathrm{W}_{\mathrm{i}, \mathrm{j}}$ is width of the street. If number of available vehicles in a cell exceeds from maximum possible number, the surplus will be transferred to the previous cell.

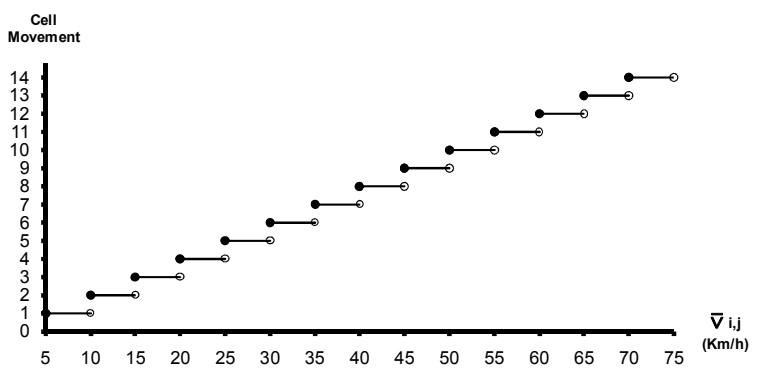

Fig. 5. Chart of cell transition (cell movement) of USCA [21].

\section{3) Third Layer}

Priority of streets and number of full cells behind the intersection are inputs of third layer of TSC [21]. Since high density in high-priority streets have more undesirable effects, priority is selected as input for adjusting the traffic signal. Also, the number of stopped vehicles behind intersections is the main factor to set the proper time for changing the status of traffic signals. Therefore, this factor is also used as important factor to control the traffic signal. The green light duration of street between intersections $\mathrm{i}$ and $\mathrm{j}$ will be calculated by equation 5 . In this equation, $\mathrm{NFC}_{\mathrm{i}, \mathrm{j}}$ is integer number which shows number of full cells behind intersections and $\mathrm{P} 2 \mathrm{~T}_{\mathrm{i}, \mathrm{j}}=\left\lfloor\mathrm{P}_{\mathrm{i}, \mathrm{j}} * 9\right\rfloor+1$.

$$
G_{i, j}=N F C_{i, j} * P 2 T_{i, j}
$$

The $\mathrm{G}_{\mathrm{i}, \mathrm{j}}$ of streets around each intersection will be calculated in 7.2 seconds intervals and then the street with highest $G$ actives its green light for $G$ seconds. To prevent starvation of other streets, equation 6 is employed:

$$
\text { IF }\left(\mathrm{G}_{\mathrm{MAX}}>=2 * \mathrm{G}_{\mathrm{C}}\right) \text { THEN Change_Traffic_light }
$$

GMAX is maximum $G$ in current 7.2 seconds interval (among streets of an intersection) and $G_{c}$ is updated value of $G$ for street which already activated its green light. In the proposed TSC, green light is activated only for one of the streets [21].

\section{B. Route Guidance}

As explained before, in second layer of TSC we calculated the estimated average speed of vehicles in each street. After calculation of estimated average speeds, every TSC will calculate the Estimated Street Travel Time (ESTT) of all streets which start from neighbor intersections and ends to it by equation 7. In this equation, Length $h_{i, j}$ is length of street which starts from intersection $i$ to intersection $j, \bar{v}_{i, j}$ is estimated average speed of this street (calculated by equation 2) and ESTT $i, j$ is the estimated time for passing this street. The ESTT is a suitable parameter for calculation of optimal routes.

$$
\operatorname{ESTT}_{i, j}=\frac{\text { Length }_{i, j}}{\bar{v}_{i, j}}
$$

Afterwards, every TSC creates a Street State Advertisement (SSA) packet and puts its own calculated ESTTs into it and broadcasts it. These packets also contain the sender address and a sequence number. Therefore, when a TSC receives an SSA packet, if it had not received a SSA packet with equal or greater sequence number from this sender before, it updates its own database and then forwards the packet to its neighbor TSCs except the sender. Otherwise drops it. As [5, 20], The SSA packets will be sent every 30 seconds. The structure of SSA packets has been shown in Fig. 6 .

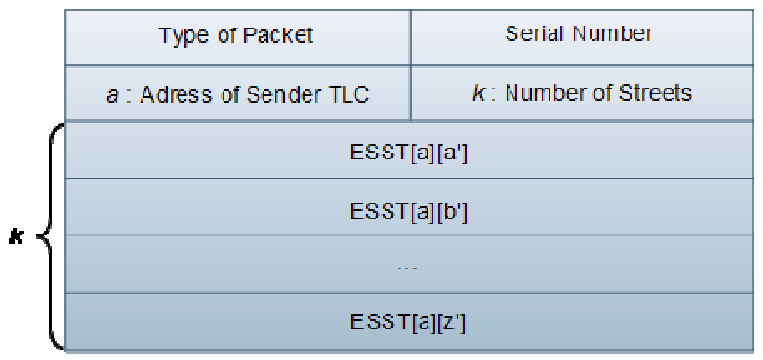

Fig. 6. The structure of SSA packets, $a$ is the address of sender TSC, $k$ is the number of its neighbor TSCs and ESST $[a]\left[i^{\prime}\right]$ means the ESST of street which starts from intersection $a$ and $i^{\prime}$.

After exchanging SSA packets between TSCs, every TSC will have the picture of whole traffic network as well as ESTT metric of each street. Every TSC calculates optimal routes from itself to other intersections by Dijkstra's shortest path algorithm [22]. Then, the drivers will be informed about optimal routes by variable message signs or by special transceivers which will be installed on vehicles. As $[5,20]$, partitioning can be used to increase convergence speed. Also, some repeaters may be needed for long streets to relay the SSA packets from one TSC to another one.

In PersianGulf, since all TSCs have whole picture of traffic network the ESTT metric of each street, a few TSCs could be connected to some places such as 1) Traffic Management Center: to collect statistics and detect failure of TSCs 2) Emergency Services e.g. 
ambulance, firehouse and police stations: to report strict and long-time congestions 3) some websites: to put realtime traffic information of traffic network on them for further use of online users or other TSCs (e.g. this information can be used by TSCs in other areas or cities to increase the scalability of PersianGulf even to several cities).

The PersianGulf is a totally distributed system because the optimal routes calculations are done in TSC nodes independently and it is totally autonomous because cooperation with either traffic supervisors such as traffic management center or the drivers does not influence system execution. Indeed, the system will work regardless to existing of any traffic supervisor or even any vehicles in the streets.

\section{SIMULATION}

To simulate PersianGulf, as [5, 20], we used a real report of input traffic to a station in Japan which has been presented in [23]. The traffic network that was used for simulation has been shown in Fig. 7 and the chart of traffic input to point $(3,1)$ of Fig. 7 has been shown in Fig. 8.

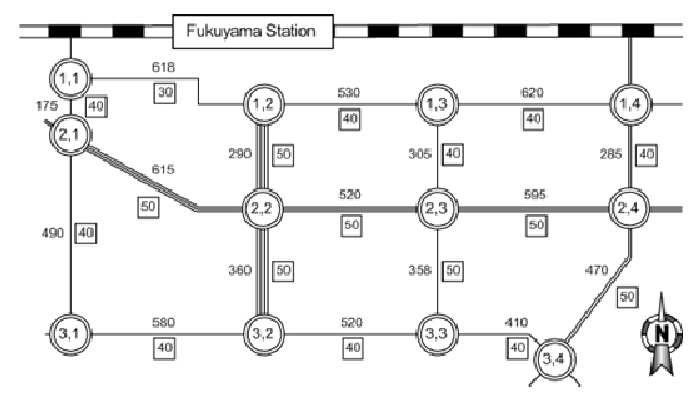

Fig. 7. Fukuyama station [23].

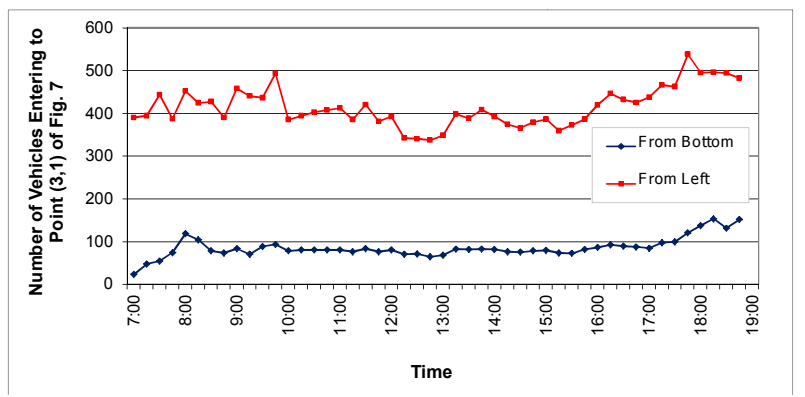

Fig. 8. Input traffic to point $(3,1)$ in a [23].

As $[5,20]$, in our simulation point $(1,4)$ in Fig. 7 has been selected as the destination point and Period Average Speed (PAS) has been used to show the results clearly. $\mathrm{PAS}_{\mathrm{t}}$ is the average speed of all vehicles which reached the destination in 15-minutes period $t$. Equation 8 shows calculation of PAS. In this equation, $\mathrm{n}_{\mathrm{t}}$ is the number of vehicles which reached the destination in period $t$, and $\bar{A}_{i, t}$ is the average speed of $i$ th vehicle reached the destination in period $t$.

$$
\operatorname{PAS}_{\mathrm{t}}=\frac{\sum_{i=1}^{\mathrm{n}_{\mathrm{t}}} \overline{\mathrm{A}}_{, \mathrm{t}}}{\mathrm{n}_{\mathrm{t}}}
$$

We simulated seven scenarios to compare the results: random routes with 30 -second 2-state traffic signals, random routes with 45 -second 2-state traffic signals, random routes with 30-second 4-state traffic signals, random routes with 45 -second 4-state traffic signals, random routes with 240 -second 8 -state traffic signals, the UTOSPF [5] routes with 240-second 8-state traffic signals and PersianGulf routes. 2-state traffic signal means that in green light durations, vehicles in two opposite directions are permitted to pass the intersection as it has been shown in Fig. 9 and 4-state traffic signal means that every direction has its own green light duration as it has been shown in Fig. 10. But, in 8-states traffic signals, more complex model of states will be used as it has been shown in Fig. 11.

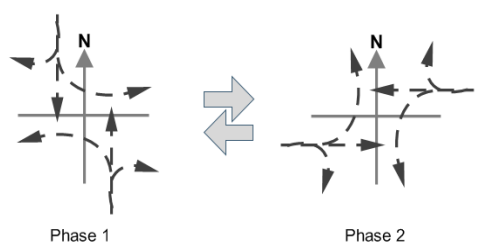

Fig. 9. The two-phase state transition model [20].

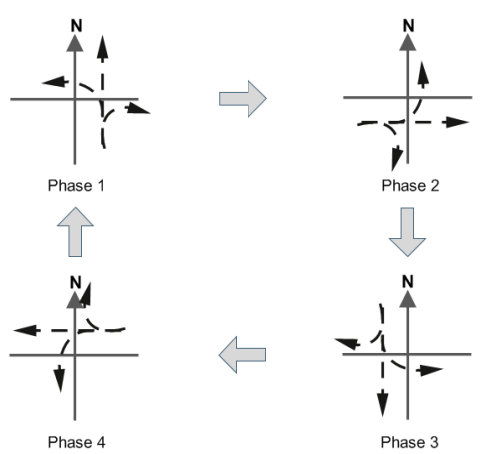

Fig. 10. The four-phase state transition model [20].

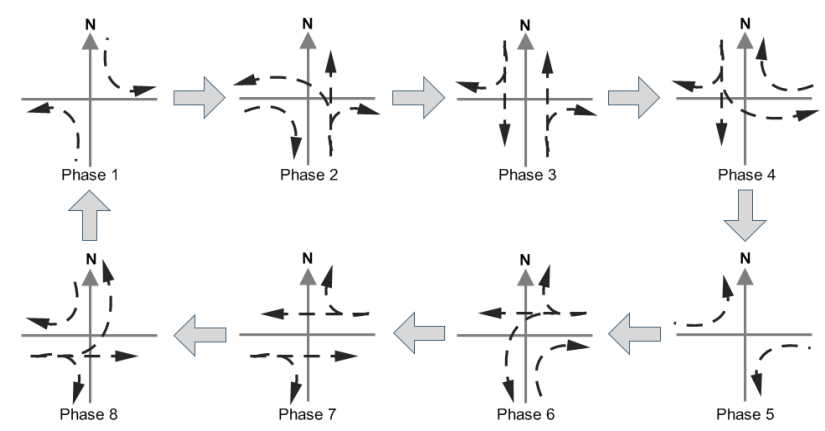

Fig. 11. The eight-phase state transition model [20]. 
The simulation results have been shown in Fig. 12. As seen the proposed system improved the PAS up to $42 \%$ as compared to random routes with 30 -seconds 2 -states traffic signals, up to $62 \%$ as compared to random routes with 45 -seconds 2 -states traffic signals, up to $101 \%$ as compared to random routes with 30-seconds 4-states traffic signals, up to $141 \%$ as compared to random routes with 45-seconds 4-states traffic signals, up to $192 \%$ as compared to random routes with 8 -states traffic signals and up to $17 \%$ as compared to UTOSFP routes with 240 second 8-states traffic signals.

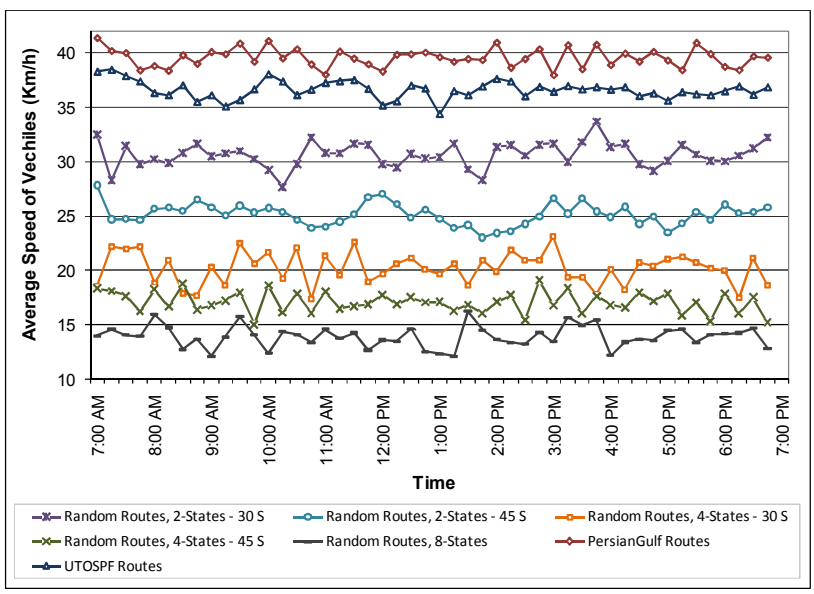

Fig. 12. The simulation results.

\section{CONCLUSION}

In this paper, a distributed autonomous combined traffic signal controller and route guidance system has been proposed. The traffic signal controller is a three layers fuzzy controller which takes into the account the priority of street as well as the queue length of stopped vehicles behind intersections. The route guidance uses the estimated average speed of vehicles in streets which calculated in second layer of traffic signal controller and calculate the estimated street travel time for each street. Then traffic signal controllers exchange their metrics with each other and will find the optimal routes from themselves to all other intersections by Dijkstra's shortest path algorithm. The simulation results showed that proposed system improves the average speed of vehicles significantly as compared to random routes with different 4-state traffic signals.

\section{REFERENCES}

[1] X. Zhi, Z. Liao, S. Zhang, "intersection-centric route guidance implementation for traffic simulation based on multi-agent," IEEE ICMLC, Hong Kong, August 2007, pp. 3844-3849.

[2] T. Kitani, T. Shinkawa, N. Shibata, K. Yasumoto, M. Ito, T. Higashino, "Efficient VANET-based traffic information sharing using buses on regular routes," IEEE VTC '08 spring, Singapore, May 2008, pp. 3031-3036
[3] Z. Yang, S. Lu, "Combined traffic signal control and route guidance: multiple user class traffic assignment model versus discrete choice model," IMACS CESA, Beijing, China, October 2006, pp. 1957-1964.

[4] Y. Yang, C. Cheng, P. Lin, S. Tsao, "A real-time road traffic information system based on a peer-to-peer approach," IEEE ISCC, Marrakech, Morocco, July 2008, pp. 513-518.

[5] K. Faez, M. Khanjary, "UTOSPF: a distributed dynamic route guidance system based on wireless sensor networks and open shortest path first protocol," IEEE ISWCS, Reykjavik, Iceland, October 2008, pp. 558-562.

[6] M. Tubaishat, Q. Qi, Y. Shang, H. Shi, "Wireless sensor-based traffic light control," IEEE CCNC, Las Vegas, NV, USA, January 2008, pp. 702-706.

[7] Y. Chong, C. Quek, P. Loh, "A novel neuro-cognitive approach to modeling traffic control and flow based on fuzzy neural techniques," Elsevier Expert Systems with Applications 36 (2009) 4788-4803.

[8] C. Xiangjun, Y. Zhaoxia, "Distributed traffic signal control approach based on multi-agent," IEEE FSKD, Tianjin, China, August 2009, pp.582-587.

[9] W. Wu, W. Min, X. Sai, "A traffic signal control method based on large phase using fuzzy system and GA," IEEE FSKD, Tianjin, China, August 2009, pp. 530-534.

[10] C. Cai, C. K. Wong, B. G. Heydecker, "Adaptive traffic signal control using approximate dynamic programming," Elsevier Transportation Research Part C 17 (2009) 456-474.

[11] G. F. List, M. Cetin, "Modeling traffic signal control using petri nets," IEEE Transactions On Intelligent Transportation Systems, Vol. 5, No. 3, September 2004, pp. 177-187.

[12] B. S. Kerner, "Empirical macroscopic features of spatial-temporal traffic patterns at highway bottlenecks," Physical Review E 65 046138, 2002.

[13] Z. Shenpei, Y. Xinping, "Driver's route choice model based on traffic signal control," IEEE ICIEA, Singapore, June 2008, pp. 2331- 2334

[14] N. H. Gartner, C. Stamatiadis, "Integration of dynamic traffic assignment with real-time traffic adaptive control system," Transportation Research Record 1644, National Research Council, Washington, D.C., USA, 1997, pp. 150-156.

[15] O. J. Chen, M. E. Ben-Akiva, "Game-theoretic formulations of interaction between dynamic traffic control and dynamic traffic assignment," Transportation Research Record 1617, National Research Council, Washington, D.C., USA, 1998, pp. 179-188.

[16] C. Lee, R. B. Machemehl, "Combined traffic signal control and traffic assignment: algorithms, implementation and numerical results," Research Report SWUTC/05/4728-00074-1, March 2005.

[17] R. LI, Q. SHI, "Study on integration of urban traffic control and route guidance based on multi-agent technology," IEEE ITSC, October 2003, pp. 1740- 1744.

[18] S. Ma, G. He, S. Wang, "A hierarchical coordination model for control-guidance integrated systems in ITS," IEEE ITSC, Singapore, September 2002, pp. 522- 527.

[19] L. Shoufeng, L. Ximin, "Based on hybrid genetic algorithm and cellular automata combined traffic signal control and route guidance," 26th Chinese Control Conference, Zhangjiajie, Hunan, China, July 2007, pp. 53-57.

[20] K. Faez, M. Khanjary, "UTOSPF with WTGLs consideration," IEEE SMC, San Antonio, Texas, USA, October 2009, pp. 41704174.

[21] M. Shakeri, A. Deldari, H. Deldari, G. Tadayon, “Three leveled fuzzy system for traffic light and urban traffic control based on cellular automata," Springer Technological Developments in Education and Automation, January 2010, pp. 477-482.

[22] E. W. Dijkstra, "A note on two problems in connexion with graphs," Numerische Mathematik, October 1959, pp. 269-271.

[23] H. Shimizu, H. Kita, "Signal control algorithms of congestion length," 36th SICE Annual Conference, 1997, pp. 1195-1200. 